\title{
Feeding practices and early childhood caries among children with primary dentition
}

\author{
Sundas $S,{ }^{1}(D)$ Sah BK, ${ }^{2}$ Dhakal N, ${ }^{3}$ Rai $A,{ }^{3}$ Joshi ${ }^{4}$
}

'Sunanda Sundas, Associate Professor, Department of Paediatric and Preventive Dentistry, People's Dental College and Hospital, Sorhakhutte, Kathmandu, Nepal; ${ }^{2}$ Barun Kumar Sah, Assistant Professor, Department of Paediatric and Preventive Dentistry, Tribhuvan University Dental Teaching Hospital, Institute of Medicine, Maharajgunj, Kathmandu, Nepal; ${ }^{3} \mathrm{Neha}$ Dhakal, ${ }^{3}$ Amita Rai, Assistant Professor; Department of Paediatric and Preventive Dentistry, People's Dental College and Hospital, Sorhakhutte, Kathmandu, Nepal; ${ }^{4}$ Neera Joshi, Associate Professor, Department of Conservative and Endodontics Department, People's Dental College and Hospital, Sorhakhutte, Kathmandu, Nepal.

\begin{abstract}
Background: Early childhood caries (ECC) is major oral health problem of young children. Risk factors for ECC are poor oral hygiene and feeding practices. Prevalence and severity of ECC is increasing with change in lifestyle and diet pattern in developing countries.

Objectives: To assess the association between feeding practices and severity of early childhood caries in preschool children.

Methods: An analytical cross-sectional study was conducted with convenient sample of 96 children up to six years age in Peoples Dental College from July to December 2020. Clinical examination included the recording of dental caries (dmft) using WHO criteria. The self-validated questionnaire consisting seven questions about feeding practices was asked to mothers. The Chi-square test was performed to determine association between severity of ECC and feeding pattern.

Results: Mean dmft was $6.77 \pm 5.91$. Prevalence of severe-ECC (S-ECC) was highest in youngest age group. Caries experience was similar in breast fed, bottle fed, and mixed. There was no significant difference in non-severe ECC and ECC in relation to duration of breast or bottle feeding but frequency of night feeding was associated with S-ECC. Children given ready-made infant formula solid food had more S-ECC $(13,92 \%)$ compared to non-severe ECC $(1,7.1 \%)$ which was statistically significant. Children given homemade gram flour food were noted to have less of S-ECC (5, 27.5\%) than nonsevere ECC $(13,72.5 \%)$ which was statistically significant.

Conclusion: Present study revealed that multiple night feeding and weaning with readymade food are significant factors for S-ECC.
\end{abstract}

Key words: Early childhood caries; Feeding practice; Severe early childhood caries.

Access this article online

Website: www.jkmc.com.np

DOI: https://doi.org/10.3126/jkmc.v10i2.40017

\section{HOW TO CITE}

Sundas S, Sah BK, Dhakal N, Rai A, Joshi N. Feeding practices and early childhood caries among children with primary dentition. J Kathmandu Med Coll. 2021;10(2):74-9.

\begin{tabular}{|l} 
Address for correspondence \\
\hline Dr. Sunanda Sundas \\
Associate Professor, \\
Department of Paediatric and Preventive Dentistry, \\
People's Dental College and Hospital, \\
Sorhakhutte, Kathmandu, Nepal. \\
E-mail: sunandapedo@yahoo.com
\end{tabular}

Copyright $\odot 2021$ Journal of Kathmandu Medical College (JKMC) ISSN: 2019-1785 (Print), 2091-1793 (Online)

This work is licensed under a Creative Commons Attribution-Non Commercial 4.0 International License.

\section{INTRODUCTION}

7 arly childhood caries (ECC) is presence of one or more

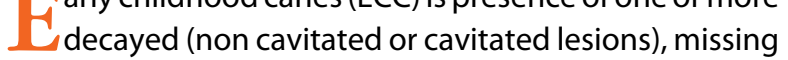
(due to caries), or filled tooth surfaces in any primary tooth in children under 71 months. In under three years children, any sign of smooth-surface caries is indicative of severe early childhood caries (S-ECC) whereas from three to five years one or more cavitated, missing due to caries, or filled smooth surfaces in primary maxillary anterior teeth, or decayed, missing, or filled score of $\geq 4, \geq 5$, or $\geq 6$ (at ages three, four, and five respectively) surfaces constitute S-ECC.' Children's quality of life is affected by severe caries because of pain and discomfort. ${ }^{2}$ Risk factors for ECC are poor oral hygiene and certain feeding practices. ${ }^{3}$ Breastfeeding after 12 months is risk factor for ECC in infants. ${ }^{4}$ Prolonged bottle-feeding with milk or sweet fluid, on-demand nocturnal breastfeeding, 
delayed weaning, consumption of sweetened food, and confectionery are also ECC risk factors. ${ }^{5}$ Prevalence of caries is increasing with change in lifestyle and diet pattern in developing countries. ${ }^{6}$ This study aimed to assess caries experiences in children below six years and to evaluate the relationship of severity of ECC with feeding patterns.

\section{METHODOLOGY}

An analytical cross-sectional quantitative study was conducted with a convenient sample of 96 children aged one to six years, in Kathmandu, Nepal from July to December 2020. Sample size of 96 was calculated by using the formula $\mathrm{n}=\mathrm{z}^{2} \mathrm{pq} / \mathrm{d}^{2}$ with a confidence interval of $95 \%$, margin of error $10 \%$, and an estimate based on the prevalence of dental caries (52\%) in indigenous Chepang schoolchildren of age five to six years old? Ethical clearance was obtained from the institutional review committee (Ref no $1 \mathrm{CH}$ No 11. 2077/2078) of People's Dental College and Hospital (PDCH). Children attending the paediatric department of PDCH meeting the following inclusion criteria were enrolled in the study: healthy and normal children, aged one to six years, with dental caries in primary teeth. Children with permanent tooth/teeth and medical disorders were excluded. An informed consent was obtained from the parents before clinical examination of their children.

Clinical examination was carried out by the single dentist using a mouth mirror and blunt explorer on the dental chair with a good dental light. Evaluation of caries was done based on the World Health Organisation (WHO) criteria. Specific codes from the caries status were subsequently used for calculation of the " $\mathrm{dmft}^{\text {" index }}$ score in which d denoted Decayed or "Filled with decay", $f$ denoted "Filled with no decay", $m$ denoted "Missing due to caries" and t denoted "Teeth".

The criteria of the American Academy of Pediatric Dentistry were used to categorise Severe Early Childhood Caries. ${ }^{8} \mathrm{~A}$ structured questionnaire was prepared after literature review and discussion with experts. A pilot study was carried out among 10 parents for validation of questions. A questionnaire consisting of seven questions was used for collecting all the required and relevant information from mothers. The questions had two to four options among which responding mothers were asked to tick the correct answers. The recorded data were analysed using Statistical Package for Social Sciences version 16 software (SPSS Inc., Chicago, IL, USA). Descriptive statistics included computation of frequency, percentages, and mean. The Chi-square test $(\chi 2)$ was used for analysis. For all tests, confidence interval and p-value were set at $95 \%$ and $<0.05$, respectively.

\section{RESULTS}

The study was carried out in 96 children aged one to six years, among which 54 (56.25\%) were males and 42 (43.75\%) were female (Table 1). Mean dmf was found to be $6.77 \pm 5.91$.

Table 1 shows the occurrence of Early Childhood Caries (ECC) which is not severe and is denoted by non-severe ECC and Severe Early Childhood Caries (S-ECC). S-ECC and non-severe ECC present in 60 (62.5\%) and 36 (37.5\%) of both male and female children respectively which was found to be statistically significant ( $p$-value $<0.001$ ). There was no significant difference in distribution in occurrence of caries in different sex. The prevalence of S-ECC was the highest in the youngest group of two and the severity of ECC was found to be in decreasing order with increasing age (Table 2).

Table 3 describes the relationship between the proportion of severity of ECC and mothers' feeding practices. The majority $(50,52 \%)$ of the children were breast-fed, 16 (16.66\%) were given infant formula or cow's milk in a bottle and the rest were mixed: breast and bottle-fed.

The prevalence of S-ECC in children solely breast-fed, bottle-fed and mixed-fed was $32(64 \%), 10$ (62\%), and $18(60 \%)$ respectively which was similar in all groups. In the breast-fed group, the majority of children (52, $54.16 \%)$ were fed for two years. There was no difference in the prevalence of S-ECC in relation to duration of breastfeeding.

Among bottle-fed children, the majority of them (47, 48.95\%) were bottle-fed for more than three years and there was no significant difference in non-severe ECC and S-ECC in relation to the duration of bottle feeding.

The frequency of night feeding is in direct relationship with the increase in severity of ECC. There was a significant difference in the occurrence of ECC without severity and S-ECC in the children who were fed three times or more during the night (Table 3 ).

Children who were given ready-made infant formula food (like Cerelac) have more occurrence of S-ECC (13, $92 \%)$ compared to non-severe ECC $(1,7.1 \%)$ which was found to be statistically significant. Children who were given homemade gram flour food like "lito" were noted to have less S-ECC $(5,27.5 \%)$ than non-severe ECC $(13$, 
72.5\%) which was highly statistically significant. There was not much of a difference in ECC without severity and S-ECC occurrence of rice and pulses or mixed type of food (Table 4).

The children who were given confectionery or biscuits had the most S-ECC (Table 5). It was seen that 50 $(68.5 \%)$ children who were given confectionery and biscuits had S-ECC and 23 (24\%) children were not given confectionery and biscuits and only 10 (43.5\%) had S-ECC. The difference between non-severe ECC and
S-ECC occurrence with or without intake of confectionery and biscuits was statistically significant ( $p=0.03$, Table 5 ).

Regarding the association of S-ECC with water given after food, in children given water after food ECC without severity and S-ECC were observed to be similar 20 (48.8\%) and 21 (51.2\%) respectively which was not a significant difference (Table 6). The children who were not given water after milk or food did have more of S-ECC which was statistically significant (Table 6).

\section{Table 1: Non-severe early childhood caries and severe early childhood caries in different sex}

\begin{tabular}{|lcc|c}
\hline Sex & $\begin{array}{c}\text { Non-severe Early Childhood Caries (ECC) } \\
\mathbf{n}(\%)\end{array}$ & $\begin{array}{c}\text { Severe Early Childhood Caries (S-ECC) } \\
\mathbf{n}(\%)\end{array}$ & p-value \\
\hline Male & $18(33.3)$ & $36(66.7)$ & 0.001 \\
\hline Female & $18(42.9)$ & $24(57.1)$ & $\mathbf{6 0 ( 6 2 . 5 )}$ \\
\hline Total & $36(37.5)$ & &
\end{tabular}

Table 2: Age distribution of non-severe early childhood caries and severe early childhood caries

\begin{tabular}{cccc}
\hline Age in years & $\begin{array}{c}\text { Non-severe ECC } \\
\mathbf{n}(\%)\end{array}$ & $\begin{array}{c}\text { S-ECC } \\
\mathbf{n}(\%)\end{array}$ & Total \\
2 & - & $7(100)$ & 7 \\
3 & $1(8.3)$ & $11(91.7)$ & 12 \\
4 & $11(30.6)$ & $25(69.4)$ & 36 \\
5 & $12(44.4)$ & $15(55.6)$ & 37 \\
6 & $12(85.7)$ & $2(14.3)$ & 14 \\
\hline Total & $\mathbf{3 6}(\mathbf{3 7 . 5}$ & $\mathbf{6 0 ( 6 2 . 5 )}$ & $\mathbf{9 6}$ \\
\hline
\end{tabular}

Table 3: Association of severe early childhood caries and method of feeding

\begin{tabular}{|c|c|c|c|c|c|}
\hline Item & & n (\%) & $\begin{array}{c}\text { Non severe-ECC } \\
\mathbf{n}(\%)\end{array}$ & $\begin{array}{l}\text { S-ECC } \\
\text { n (\%) }\end{array}$ & p-value \\
\hline \multirow{3}{*}{$\begin{array}{l}\text { Type of milk given to } \\
\text { baby }\end{array}$} & Mothers milk (breast-fed) & $50(52)$ & $18(36)$ & $32(64)$ & 0.75 \\
\hline & Cow's/ formula milk (bottle-fed) & $16(16.66)$ & $63(7)$ & $10(62)$ & 0.73 \\
\hline & $\begin{array}{l}\text { Mixed } \\
\text { (breast and bottle) }\end{array}$ & $30(31.25)$ & $12(40)$ & $18(60)$ & 1.00 \\
\hline \multirow{4}{*}{$\begin{array}{l}\text { Duration of } \\
\text { breastfeeding }\end{array}$} & Till one year & $10(10.41)$ & $4(40)$ & $6(60)$ & 0.8613 \\
\hline & Till two years & $52(54.16)$ & $23(40)$ & $29(55.8)$ & 0.1386 \\
\hline & Till three years & $17(17.7)$ & $8(44.4)$ & $9(70.4)$ & 0.3191 \\
\hline & More than three years & $9(9.37)$ & $1(14.3)$ & $6(66.6)$ & 0.1878 \\
\hline \multirow{4}{*}{$\begin{array}{l}\text { Duration of bottle } \\
\text { feeding }\end{array}$} & Till one year & $16(16.66)$ & $5(31.2)$ & $11(66.8)$ & 0.5716 \\
\hline & Till two years & $18(18.75)$ & 7 (38.9) & $11(61.1)$ & 0.8926 \\
\hline & Till three year & $15(15.62)$ & $7(46.7)$ & $8(53.3)$ & 0.4247 \\
\hline & More than three years & $47(48.95)$ & $17(36.2)$ & $30(63.8)$ & 0.7921 \\
\hline \multirow{4}{*}{$\begin{array}{l}\text { Frequency of milk } \\
\text { feeding during night }\end{array}$} & One time & $20(20.83)$ & $6(30)$ & $14(70)$ & 0.4362 \\
\hline & Two times & 19 (19.79) & $9(47.4)$ & $10(52.6)$ & 0.321 \\
\hline & Three times & $27(28.12)$ & $15(25.9)$ & $12(44.4)$ & 0.0223 \\
\hline & More than three times & $30(31.25)$ & $7(23.3)$ & $23(76.2)$ & 0.05 \\
\hline
\end{tabular}


Table 4: Association of severe early childhood caries and type of weaning

\begin{tabular}{|c|c|c|c|c|}
\hline Type of food & $\begin{array}{c}\text { Non-severe } \\
\text { ECC, n (\%) }\end{array}$ & $\begin{array}{l}\text { S-ECC } \\
\text { n (\%) }\end{array}$ & $\begin{array}{l}\text { Total } \\
\text { n (\%) }\end{array}$ & p-value \\
\hline Ready-made infant formula food (Cerelac) & $1(7.1)$ & $13(92 \%)$ & $14(14.6)$ & 0.0251 \\
\hline Homemade gram flour food (Lito) & $13(72.5)$ & $5(27.5)$ & $18(18.7)$ & 0.0007 \\
\hline Rice and pulses & $5(44.4)$ & $4(5.6)$ & $9(9.4)$ & 0.4158 \\
\hline Cerelac, rice and pulse & $7(45.7)$ & $9(56.3)$ & $16(16.7)$ & 0.5716 \\
\hline Cerelac and lito & $8(32)$ & $17(68)$ & $25(26)$ & 0.5089 \\
\hline Lito, rice and pulse & $2(14.3)$ & $12(85.7)$ & $14(14.6)$ & 0.1005 \\
\hline
\end{tabular}

Table 5: Association of severe early childhood caries and additional food

\begin{tabular}{lcccc} 
Confectionery and biscuits & $\begin{array}{c}\text { Non-severe ECC, } \\
\mathbf{n}(\%)\end{array}$ & $\begin{array}{c}\text { S-ECC } \\
\mathbf{n}(\%)\end{array}$ & $\begin{array}{c}\text { Total } \\
\mathbf{n}(\%)\end{array}$ & p-value \\
\hline Given & $23(31.5)$ & $50(68.5)$ & $73(76)$ & 0.03 \\
Not given & $13(56.5)$ & $10(43.5)$ & $23(24)$ & \\
\hline Total & $\mathbf{3 6}$ & $\mathbf{6 0}$ & & \\
\hline
\end{tabular}

Table 6: Association of severe early childhood caries with water given after food

\begin{tabular}{lcccc}
\hline Water after food & Non-severe ECC, $\mathbf{n}(\%)$ & S-ECC & Total & p-value \\
\hline Given & $20(48.8)$ & $21(51.2)$ & $41(42.7)$ & 0.3766 \\
Not given & $16(29.1)$ & $39(70.9)$ & $55(55.3)$ & 0.048 \\
\hline Total & $\mathbf{3 6}$ & $\mathbf{6 0}$ & $\mathbf{9 6}$ & \\
\hline
\end{tabular}

\section{DISCUSSION}

In recent years, a significant proportion of preschoolers, in developing countries, are affected by ECC. ${ }^{9}$ Increase in severity of ECC could be due to globalisation, urbanisation, and change in lifestyle. ${ }^{10}$ In this present study, dmft index was found to be $6.77 \pm 5.9$, and 60 $(62.5 \%)$ children had the severe form of ECC. There was no significant difference in the distribution of ECC in sex which is similar to earlier reports given by O'Sullivan et al. (1994), ${ }^{11}$ Hattab et al. (1999), ${ }^{12}$ and Qadri et al. (2012). ${ }^{13}$ Early childhood caries increases by age due to prolonged exposure to cariogenic risk factors. ${ }^{14}$ The present study also showed a higher prevalence of ECC with increasing age but S-ECC was seen highest among the children of two years old.

The best prevention of dental caries in children is possible by identification and avoidance of causative factors which are associated with feeding practices. Breastfeeding recommended by health care professionals, however, done in a prolonged manner, at night has been reported to be a potential risk factor for the development of ECC. ${ }^{15,16}$ In the present study, breastfeeding was found to be the dominant mode of feeding followed by mixed: breastfeeding and bottle feeding. However, there was no significant relation between caries occurrence and the type of feeding whether, breast, bottle, or mixed which is in accordance with a study done by Rosenblatt and Zarzar among the Brazilian children. ${ }^{17}$ Severity of caries in the present study also did not depend on breastfeeding practice which is similar to that reported by Dorah and Glady in 2018. ${ }^{18}$

The literature suggested that prolonged natural breastfeeding after 12 months was a risk factor for the occurrence of ECC in infants. ${ }^{5}$ In the present study, there was no significant difference between non severe ECC and S-ECC in children in relationship with duration of breastfeeding which is in accordance with the report was given by Almushtayat. ${ }^{19}$ This was also similar to the report given by Dorah and Glady (2018) which showed no significant differences between the breastfeeding period and severe ECC and those without decay. ${ }^{18}$ However, findings of Hattab et al. (1999), Dini et al. (2000) and Prakash et al. (2013), showed that prolonged breastfeeding is associated with ECC. ${ }^{12,16,20}$

Bottle feeding predisposes to ECC because the nipple of the bottle reduces or blocks the access of saliva flow, particularly in upper incisors causing food stagnation in the teeth and prolonged exposure to fermentable carbohydrates. ${ }^{21}$ In this study, the prevalence of S-ECC was more in children with bottle feeding which is always harmful irrespective of duration. This finding was in 
accordance with study by Almushayt et al. which reports a highly significant relation between the two groups: children going to bed with a feeding bottle or without bottle feeding $(p<0.001)$ and the odds ratio $(0.09) .{ }^{19}$ The prevalence of ECC is related to the duration of bottle feeding as shown by an earlier study done by Febres (1997). ${ }^{22}$ Rusali et al. reported the prevalence of ECC to be significantly $(p<0.001)$ high among children who were bottle-fed for more than four years. ${ }^{23}$ Similarly, in Jeddah (Saudi Arabia) it was observed that children who bottlefed in bed had a $9 \%$ greater risk of caries compared to children who did not. ${ }^{19}$ Another study from south-west Germany reported a significant correlation between the usage of nursing bottles in bed and severe ECC. ${ }^{24}$

In the present study, S-ECC was significantly high in children who were fed three or more times during the night with $p$-value 0.02 and 0.05 respectively. A similar report was given by Prakash et al. which states that caries was high in children breast-fed about five times a day. ${ }^{16}$ Study by Almushayt et al. also reported that occurrence of S-ECC was significantly more among children breast or bottle fed more than once daily. ${ }^{19}$

In Nepal, weaning is usually started at the age of four to six months with traditional food. Nowadays there is change in trend due to busy schedule of mothers. Babies are given ready-made infant formula containing starch, sucrose, and lactose which predisposes to caries. In the present study, S-ECC was found to be significantly high in children who were weaned with ready-made infant formula food ( $p=0.02$ ) in contrast, significantly less S-EEC $(p=0.0007$ ) was found in children whose weaning food contained only gram flour. It shows the weaning foods influence the presence and severity of ECC. According to Moynihan and Petersen (2004) consumed starchy food is broken down into glucose, maltose, and maltotriose, by salivary amylase ${ }^{25}$ which later is metabolized by oral bacteria to produce acids. Mixture of starch and high sucrose concentration in food is more cariogenic than starch alone. ${ }^{26}$ Studies also report that children with ECC have a history of a high frequency of sugar consumption,

\section{REFERENCES}

1. Alazmah A. Early childhood caries: A review. J Contemp Dent Pract. 2017;18(8):732-7. [PubMed | Full Text | DOI]

2. Petersen PE, Estupinan-Day S, Ndiaye C. WHO's action for continuous improvement in oral health Bulletin of the World Health Organization. 2005:83(9):642. [PubMed | Full Text] not only of fluids given in a nursing bottle but also of sweetened solid foods. ${ }^{27,28}$

In the present study, 50 (68.5\%) children were given confectionery and biscuits had significantly high S-ECC. But children who were not given confectionery and biscuits had significantly less S-ECC $(p=0.03)$. The direct relationship between the frequency of intake of sweets and sticky snacks and the incidence of dental caries has been proven by Gustaffson (1954) in the Vipeholm study..$^{19}$ Introduction of sugary drinks and confectionery at an early age is known to lead to the establishment of cariogenic food habits that persisted in later ages. ${ }^{29}$

Water intake immediately after food in children is essential in removing the food from the oral cavity and to reduce the possibilities of caries initiation. A significant difference in the severity of caries was noted in the present study between children who were not given water immediately after food $(p=0.04)$. No significant difference in ECC severity was noted when children were given water after food. Mouth cleaning after eating sweets, brushing for at least three minutes after eating reduces the occurrence of caries and effectively predicts the deft or DMFT index of school children in Xiulin Township (R2 $1 / 40.218, p<0.0001) .{ }^{30}$

\section{CONCLUSION}

Early childhood caries a multifactorial disease, severity of which is increasing among some age groups for some other reasons. The present study identified feeding practice to be the main cause for increase in severity of ECC. Bottle feeding, nocturnal feeding, and introduction of refined ready-made food of infant formula have been associated with increased caries prevalence. The challenge may be overcome by promoting noncariogenic diet, discouraging cariogenic diet and establishing good feeding practices.

\section{Conflict of interest: None \\ Source(s) of support: None}

3. Tinanoff $\mathrm{N}$, Reisine S. Update on early childhood caries since the Surgeon General's Report. Acad Pediatr. 2009;9(6):396-403. [PubMed |Full Text |DOI]

4. Cui L, Li X, Tian Y, Bao J, Wang L, Xu D, et al. Breastfeeding and early childhood caries: a metaanalysis of observational studies. Asia Pac J Clin Nutr. 2017;26(5):867-80. [PubMed | Full Text | DOI]

5. Tinanoff N, O'Sullivan DM. Early childhood caries: overview and recent findings. Pediatr Dent. 1997 Jan-Feb;19(1):12-6. [PubMed | Full Text] 
6. Rao A, Sequeira SP, Peter S. Prevalence of dental caries among school children of Moodbidri. J Indian Soc Pedod Prev Dent. 1999 Jun;17(2):45-8. [PubMed | Full Text]

7. Dixit LP, Shakya A, Shrestha, M, Shrestha A. Dental caries prevalence, oral health knowledge and practice among indegenous Chepang school children of Nepal. BMC Oral Health. 2013;13:20. [PubMed | Full Text |DOI]

8. Policy on Early Childhood Caries (ECC): Classifications, Consequences, and Preventive Strategies. Pediatr Dent. 2016;79-81. [PubMed | Full Text]

9. Agarwal V, Nagarajappa R, Keshavappa SB, Lingesha RT. Association of maternal risk factors with early childhood caries in schoolchildren of Moradabad, India. Int J Paediatr Dent [Internet]. 2011;21(5):382-8. [PubMed | Full Text | DOI]

10. Marthaler TM. Changes in dental caries 1953-2003. Caries Res.; 2004;38(3):173-81. [PubMed | Full Text | DOI]

11. O'Sullivan DM, Douglass J, Champany R, Eberling S, Tetrev S, Tinanoff N. Dental caries prevalence and treatment among Navajo preschool children. J Public Health Dent. 1994;54(3):139-44. [PubMed | Full Text |DOI]

12. Hattab FN, Al-Omari MA, Angmar-Månsson B, Daoud $\mathrm{N}$. The prevalence of nursing caries in one-to-fouryear-old children in Jordan. ASDC J Dent Child. 1999 Jan-Feb;66(1):53-8. [PubMed | Full Text]

13. Qadri G, Nourallah A, Splieth $\mathrm{CH}$. Early childhood caries and feeding practices in kindergarten children. Quintessence Int. 2012 Jun;43(6):503-10. [PubMed | Full Text]

14. Zaki NA, Dowidar KM, Abdelaziz WE. Assessment of the Healthy Eating Index-2005 as a predictor of early childhood caries. Int J Paediatr Dent. 2015 Nov;25(6):436-43. [PubMed | Full Text | DOI]

15. Gartner LM, Morton J, Lawrence RA, Naylor AJ, O'Hare $D$, Schanler RJ, et al. American Academy of Pediatrics Section on Breastfeeding. Breastfeeding and the use of human milk. Pediatrics. 2005 Feb;115(2):496-506. [PubMed | Full Text | DOI]

16. Dini EL, Holt RD, Bedi R. Caries and its association with infant feeding and oral health-related behaviours in 3-4-year-old Brazilian children. Community Dent Oral Epidemiol. 2000 Aug;28(4):241-8. [PubMed | Full Text | DOI]

17. Rosenblatt A, Zarzar P. Breast-feeding and early childhood caries: an assessment among Brazilian infants. Int J Paediatr Dent. 2004 Nov;14(6):439-45. [PubMed | Full Text | DOI]

18. Dorah W, Gladys O. Infant Feeding, Weaning Practices and Oral Hygiene Status of 3-5-Year-Old Children with Severe Early Childhood Caries and
Children without Caries in Kisumu, Kenya. Controlled Trial. Mod App Dent Oral Health. 2018;2(1). MADOHC. MS.ID.000128. [Full Text | DOI]

19. Almushayt AS, Sharaf AA, Meligy OS El, Tallab HY. Dietary and Feeding Habits in a Sample of Preschool Children in Severe Early Childhood Caries (S-ECC). J King Abdulaziz Univ - Med Sci. 2009;16(4):13-36. [Full Text | DOI]

20. Prakasha Shrutha S, Vinit GB, Giri KY, Alam S. Feeding practices and early childhood caries: a cross-sectional study of preschool children in kanpur district, India. ISRN Dent. 2013 Dec 5;2013:1-6. [PubMed | Full Text | DOI]

21. Seow WK. Biological mechanisms of early childhood caries. Community Dent Oral Epidemiol. 1998;26(1 Suppl):8-27. [PubMed | DOI]

22. Febres C, Echeverri EA, Keene HJ. Parental awareness, habits, and social factors and their relationship to baby bottle tooth decay. Pediatr Dent. 1997 JanFeb;19(1):22-7. [PubMed | Full Text]

23. Rusali R, Hamali NN, Razi FM, Mustafa N, Harun NA, Shukri NAM. Early Childhood Feeding Practices and Its Association with Early Childhood Caries. J Food Nutr Res. 2019;7(11):801-4. [Full Text | DOI]

24. Bissar A, Schiller P, Wolff A, Niekusch U, Schulte AG. Factors contributing to severe early childhood caries in south-west Germany. Clin Oral Investig. 2014;18(5):1411-8. [PubMed | Full Text | DOI]

25. Moynihan P, Petersen PE. Diet, nutrition and the prevention of dental diseases. Public Health Nutr. 2004;7(1A):201-26. [PubMed | Full Text | DOI]

26. Weinstein $P$, Domoto $P$, Wohlers $K$, Koday M. MexicanAmerican parents with children at risk for baby bottle tooth decay: pilot study at a migrant farmworkers clinic. ASDC J Dent Child. 1992 Sep-Oct;59(5):376-83. [PubMed | Full Text]

27. Tsubouchi J, Tsubouchi M, Maynard RJ, Domoto PK, Weinstein P. A study of dental caries and risk factors among Native American infants. ASDC J Dent Child. 1995 Jul-Aug;62(4):283-7. [PubMed | Full Text]

28. Al Ghanim NA, Adenubi JO, Wyne AA, Khan NB. Caries prediction model in pre-school children in Riyadh, Saudi Arabia. Int J Paediatr Dent. 1998 Jun;8(2):11522. [PubMed | Full Text |DOI]

29. Wendt LK, Hallonsten AL, Koch G, Birkhed D. Analysis of caries-related factors in infants and toddlers living in Sweden. Acta Odontol Scand. 1996 Apr;54(2):1317. [PubMed | Full Text | DOI]

30. Cheng $\mathrm{YC}$, Huang $\mathrm{HK}, \mathrm{Wu} \mathrm{CH}$, Chen $\mathrm{CC}$, Yeh Jl. Correlation between dental caries and diet, oral hygiene habits, and other indicators among elementary school students in Xiulin Township, Hualien County, Taiwan. Tzu Chi Med J. 2014;26(4):175-81. [Full Text] 